\title{
MULTIMEDIA INTERAKTIF BERBASIS COURSE LAB DALAM PEMBELAJARAN MEMAHAMI DASAR-DASAR ELEKTRONIKA
}

\author{
Fivia Eliza ${ }^{1}$, Novi Pranata ${ }^{2}$, Radinal Fadli ${ }^{3}$ \\ 1,2,3 Jurusan Teknik Elektro, Fakultas Teknik, Universitas Negeri Padang \\ e-mail: ${ }^{1}$ novipranata12@gmail.com, ${ }^{2}$ fivia eliza@.ft.unp.ac.id, ${ }^{3}$ fadliradinal@gmail.com
}

\begin{abstract}
This research is motivated by One-way learning media using whiteboard media, presentation media such as power point media which causes students to decrease motivation to learn and improve student learning outcomes. The purpose of this study was to produce interactive multimedia products based on the Course Lab. This type of research is development research (Research and Development). This study uses the ADDIE Model which consists of 5 stages, namely analysis, design, development, implementation, and evaluation. The results of the development obtained by interactive multimedia based on Course Lab and the results of the study obtained Interactive Multimedia-based Course Lab validation worth 4.12 with the valid category. Thus it can be used as learning media. The test results practicalities of the subject teachers and students of the Interactive Multimedia Course Based Lab obtained with a level of practicality of the subject teachers at 4,17 on the category of practical and student responses on the Interactive Multimedia obtained at 4,01 on Practical category. And the effectiveness of the use of Interactive Multimedia Based Course Lab obtained from students' classical mastery level is 87,5\% of Minimum Criterion Criterion (KKM) of 80 .
\end{abstract}

Keywords: Interactive Multimedia, Course Lab, ADDIE, Validity

\section{INTISARI}

Penelitian ini dilatar belakangi oleh penggunaan media pembelajaran satu arah menggunakan media papan tulis, media presentasi seperti media power point yang menyebabkan menurunnya motivasi siswa untuk belajar dan mempengaruhi hasil belajar siswa. Tujuan penelitian ini adalah untuk menghasilkan produk berupa multimedia interaktif berbasis Course Lab. Jenis penelitian ini adalah penelitian pengembangan (Research and Development). Penelitian ini menggunakan Model ADDIE yang terdiri dari 5 tahap yaitu analisis (analysis), perancangan (Design), pengembangan (Development), implementasi (Implementation), evaluasi (Evaluation). Dari hasil pengembangan didapatkan multimedia interaktif berbasis Course Lab dan hasil penelitian diperoleh data validasi Multimedia Interaktif Berbasis Course Lab sebesar 4,12 dengan kategori Valid. Dengan demikian dapat digunakan untuk pembelajaran. Hasil uji praktikalitas kepada guru mata pelajaran dan siswa mengenai Multimedia Interaktif Berbasis Course Lab diperoleh dengan tingkat kepraktisan dari guru mata pelajaran sebesar 4,17 pada kategori praktis dan tanggapan siswa mengenai Multimedia Interaktif diperoleh sebesar 4,01 pada kategori Praktis. Dan efektifitas penggunaan Multimedia Interaktif Berbasis Course Lab diperoleh dari tingkat ketuntasan klasikal siswa yaitu 87,5\% dari Kriteria Ketuntasan Minimun (KKM) sebesar 80.

Kata Kunci: Multimedia Interaktif, Course Lab, ADDIE, Valid 


\section{PENDAHULUAN}

Perkembangan teknologi yang semakin pesat memberikan pengaruh yang luar biasa pada berbagai aspek kehidupan, termasuk dalam dunia pendidikan. Tujuan utama teknologi dalam Pendidikan adalah untuk memecahkan masalah belajar atau memfasilitasi kegiatan pembelajaran tersebut. Pendidikan di Indonesia diharapkan mampu menghasilkan sumber daya manusia yang demokratis, religius, berjiwa mandiri, menjunjung tinggi harkat kemanusiaan, dan menekankan keunggulan di berbagai bidang sehingga mencapai kemajuan dan kemakmuran. Perkembangan Ilmu Pengetahuan dan Teknologi (IPTEK) juga turut menuntut sumber daya manusia yang handal dan mampu berkompetisi secara global.

Sekolah Menengah Kejuruan (SMK) merupakan pendidikan formal pada tingkat menengah yang membekali peserta didik dengan keterampilan dalam bidang tertentu untuk menghadapi dunia kerja. Secara tidak langsung, SMK memiliki peranan penting dalam pembangunan nasional khususnya dalam mempersiapkan tenaga kerja yang terampil dan terdidik. Sejalan dengan tujuan tersebut, maka kualitas lulusan SMK harus ditingkatkan. Peningkatan kualitas lulusan SMK hendaknya disertai dengan kualitas proses pembelajaran didalam kelas. Dari hasil observasi dan pengamatan yang dilakukan di SMK Muhammadiyah 1 Padang di kelas XI program keahlian Teknik Instalasi Tenaga Listrik (TITL) pada mata pelajaran Memahami Dasar-Dasar Elektronika (MDDE) ditemukan beberapa kendala yakni Proses pembelajaran di SMK masih berfokus pada guru, serta penggunaan media pembelajaran satu arah menggunakan media papan tulis, media presentasi seperti media power point, sehingga siswa tidak termotivasi mengikuti proses pembelajaran. Kondisi tersebut tentu berdampak pada hasil belajar siswa yang masih rendah. Hal ini dapat dilihat dari hasil ujian akhir siswa kelas XI mata pelajaran MDDE di SMK Muhammadiyah 1 Padang. Hal tersebut dapat dilihat pada tabel 1 .
Tabel 1. Nilai Ujian Akhir Semester

\begin{tabular}{|c|c|c|c|c|}
\hline \multirow[b]{2}{*}{ No. } & \multirow[b]{2}{*}{ Kelas } & \multirow[b]{2}{*}{$\begin{array}{c}\text { Jumlah } \\
\text { Siswa }\end{array}$} & \multicolumn{2}{|c|}{ Persentase Ketuntasan } \\
\hline & & & Tuntas $\geq 80$ & $\begin{array}{c}\text { Tidak } \\
\text { Tuntas } \\
\leq 80\end{array}$ \\
\hline 1 & $\begin{array}{c}\text { XI } \\
\text { TITL } \\
1\end{array}$ & 30 & $14(47 \%)$ & $16(53 \%)$ \\
\hline 2 & $\begin{array}{c}\text { XI } \\
\text { TITL } \\
2\end{array}$ & 20 & $9(45 \%)$ & $11(55 \%)$ \\
\hline & mlah & 50 & $23(46 \%)$ & $27(54 \%)$ \\
\hline
\end{tabular}

Sumber: Guru Matapelajaran

Salah satu upaya untuk menigktakan hasil belajar siswa adalah dengan mengembangkan media pembelajaran berupa multimedia interaktif yang menekankan aspek pengalaman belajar sehingga siswa dapat membangun sendiri pengetahuannya dengan pendidik sebagai fasilitator. Dengan memperhatikan kompleks dan uniknya proses belajar, maka ketepatan pemilihan media dan metode pembelajaran akan sangat berpengaruh terhadap hasil belajar siswa [1]. Penggunaan multimedia sebagai media pembelajaran dapat menyebabkan proses komunikasi antara guru dan siswa dapat terlaksana dengan baik dan lancar. Komputer mampu menampilkan multimedia seperti audio, video, gambar, text, dan animasi, sehingga mempunyai potensi untuk menjadi alat pengajaran yang dapat menyajikan materi yang abstrak menjadi lebih konkrit.

Berdasarkan permasalahan tersebut, maka perlu dikembangkan media pembelajaran dengan membuat multimedia interaktif berbasis Course Lab yang valid dalam pembelajaran Memahami Dasar-Dasar Elektronika.

\section{PENDEKATAN PEMECAHAN MASALAH \\ Media Pembelajaran}

Kata media berasal dari bahasa latin medius yang secara harfiah berarti tengah, perantara atau penghantar. Media pembelajaran adalah sebuah alat yang berfungsi untuk menyampaikan pesan pembelajaran [2]. Jadi dapat disimpulkan bahwa media pembelajaran adalah segala sesuatu baik itu hardware maupun software yang dapat digunakan untuk menyampaikan pesan/informasi dari sumber ke penerima.

Multimedia merupakan beberapa media yang dikombinasikan menjadi satu untuk 
menampilkan pesan yang akan disampaikan. Biasanya yang dikombinasikan dalam media tersebut berupa teks, audio, visual ataupun audio visual. Multimedia adalah penggunaan beberapa media yang berbeda dalam menyampaikan informasi berbentuk teks, audio, grafik, animasi dan video. Berdasarkan pengertian tersebut multimedia dapat diartikan sebagai alat penyalur informasi yang disajikan melalui teks, gambar, grafik, animasi dan video.

Interaktif berarti harus ada dua pihak yang terlibat dalam proses pembelajaran. Harus ada umpan balik antara pengguna dan media yang digunakannya. Media yang digunakan atau bahan belajar itu dapat menanggapi sikap atau langkah yang dilakukan oleh pengguna. Tanggapan atau respon harus bisa memahami langkah yang diambil oleh pemakai dan bahwa tanggapan tersebut bersifat mendidik.

Konsep interaktif dalam pembelajaran paling erat kaitannya dengan media berbasis computer [2]. Interaksi dalam lingkungan pembelajaran berbasis komputer pada umumnya mengikuti tiga unsur, yaitu (1) urut-urutan instruksional yang dapat disesuaikan, (2) jawaban atau respon atau pekerjaan siswa, dan (3) umpan balik yang dapat disesuaikan.

Jadi dapat disimpulkan bahwa Multimedia interaktif adalah suatu media yang dilengkapi oleh alat pengontrol yang dapat di operasikan oleh pengguna. Sehingga pengguna dapat memilih dan mengatur multimedia sesuai dengan apa yang dikehendaki untuk proses selanjutnya. Interaktif berarti Proses umpan balik (feedback) antara pengguna dengan media, Saat pengguna melakukan tindakan maka aplikasi tersebut merespon tindakan dari penggunanya.

\section{Aplikasi Course Lab}

Aplikasi Course Lab 2.4 merupakan aplikasi yang edukatif yang mudah diunduh. Dengan menggunakan aplikasi ini pendidik dapat membuat sebuah bahan ajar yang nantinya dapat diintegrasikan dengan Learning Management System (LMS) berbasis web, serta CD [3]. Beberapa keunggulan aplikasi Course Lab 2.4 yaitu : (a) Dapat di export kedalam bentuk Scoorm 1.2 LMS. (b) Dapat dipublikasikan ke dalam LMS (Learning Management System) tanpa harus mengubah file ekstensi, karena file sudah berbentuk dalam ekstensi. $\mathrm{html}$ yang kompatibel dengan internet system. (c) Dapat dipublikasikan ke dalam auto run- play $\mathrm{CD}$, dalam arti lain file media dapat dipublikasikan melalui compact disk atau CD. (d) Dapat langsung ditambahkan soal interaktifnya.

\section{Metodologi}

Jenis penelitian yang digunakan adalah penelitian pengembangan (research and development). Penelitian pengembangan adalah penelitian yang digunakan untuk menghasilkan produk tertentu dan menguji keefektifan produk tersebut [4]. Prosedur penelitian yang digunakan adalah model ADDIE. Proses yang dilakukan dalam pengembangan media berdasarkan konsep ADDIE dapat dilihat pada gambar berikut:

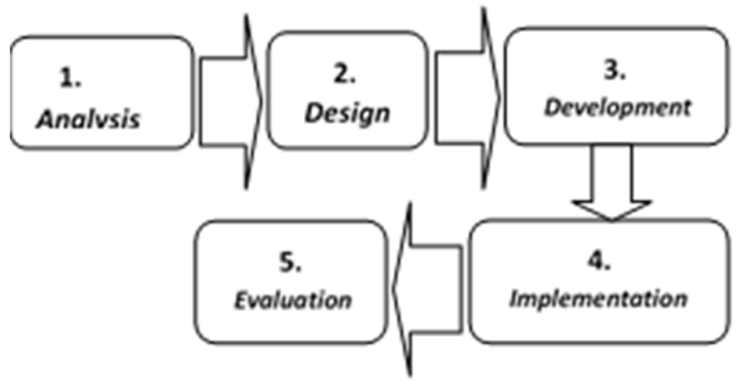

\section{Gambar 1. Langkah-Langkah Model Pengembangan ADDIE}

Subjek dalam penelitian ini adalah Multimedia Interaktif Berbasis Course Lab dalam Pembelajaran Memahami Dasar-Dasar Elektronika Kelas XI TITL 1 rombel B sebanyak 16 siswa di SMK Muhammadiyah 1 Padang.

Teknik yang digunakan dalam penelitian ini adalah teknik pengembangan menurut langkah-langkah pengembangan ADDIE dengan tahapan sebagai berikut:

1. Mengumpulkan informasi analisis kurikulum dan karakteristik siswa untuk pengembangan multimedia interaktif berupa Course Lab pada mata pelajaran MDDE dikelas XI SMK Muhammadiyah 1 Padang.

2. Membuat desain Course Lab pada materi MDDE di SMK Muhammadiyah 1 Padang.

3. Desain dan materi yang telah dibuat selanjutnya divalidasi oleh tenaga ahli. Jika ditemukan suatu kelemahan dan kekurangan pada Course Lab tersebut, maka desain tersebut harus direvisi kembali berdasarkan saran validator. Analisis validitas dilakukan dengan rumus sebagai berikut: 


$$
V=\frac{\text { Jumlah Skor Validasi }}{\text { Jumlah Pertanyaan }}
$$

4. Setelah dilakukan revisi, maka produk Course Lab pada mata pelaran MDDE diuji cobakan pada 1 orang guru mata pelajaran dan kepada siswa kelas XI TITL I rombel B. Uji coba ini dilakukan untuk melihat tanggapan dan penilaian dari guru dan siswa tentang manfaat penggunan multimedia interaktif yang telah dibuat. Kemudian akan dilakukan revisi sesuai dengan data yang diperoleh.

5. Setelah dilakukan uji coba, dimana telah didapatkan hasil belajar siswa melalui tes. Hasil belajar siswa dapat dikatakan tuntas jika telah memenuhi KKM 80. Ketuntasan klasikal atau persentase kelulusan siswa yang harus dipenuhi adalah $85 \%$. Jadi media pembelajaran dikatakan efektif jika tingkat kelulusan siswa sama atau lebih dari $85 \%$. Untuk mengetahui persentase ketuntasan klasikal siswa, digunakan persentase ketuntasan yang membandingkan ketuntasan siswa dengan jumlah keseluruhan siswa.

$$
\mathrm{PK}=\frac{J T}{J S} \times 100 \%
$$

\footnotetext{
Keterangan:

$\mathrm{PK}=$ Persentase ketuntasan

$\mathrm{JT}=$ Jumlah siswa tuntas

JS = Jumlah seluruh siswa
}

\section{HASIL DAN PEMBAHASAN}

Penelitian pengembangan ini menghasilkan sebuah produk multimedia interaktif berbasis Course Lab. Materi yang terdapat dalam multimedia interaktif yaitu tentang Memahami Sifat-Sifat Komponen Elektronika Pasif yang merupakan sebuah kompetensi dasar (KD) dalam mata pelajaran Memahami Dasar-Dasar Elektronika (MDDE). Multimedia interaktif dikemas dalam bentuk aplikasi dan dapat digunakan oleh guru maupun siswa.

Tampilan multimedia interaktif diawali dengan tampilan utama yang menampilkan judul dan gambar yang akan disajikan mengenai materi yang akan dipelajari. Selanjutnya pengguna tinggal menekan tombol arah kanan untuk melanjutkan slide berikutnya, maka tampilan akan otomatis menuju slide yang sudah dirancang.

\section{Tahap Analisis}

Tahap analisis ini dilakukan dilakukan penetapan tahap awal dalam mendesain Course Lab sesuai dengan syarat-syarat pembelajaran dengan kondisi sekolah. Tahap ini terdiri atas beberapa langkah yaitu sebagai berikut.

\section{a. Analisis Kebutuhan}

Analisis kebutuhan ini bertujuan untuk memunculkan masalah dasar yang dibutuhkan dalam pengembangan Course Lab. Analisis kebutuhan telah dilakukan oleh peneliti saat melakukan observasi, sehingga menjadi dasar pertimbangan untuk menghasilkan multimedia interaktif berbasis Course Lab.

\section{b. Analisis Siswa}

Analisis siswa merupakan telaah dari hasil belajar siswa. Analisis inilah yang akan dijadikan kerangka acuan dalam menyusun materi pembelajaran yang diperoleh dari nilai mid semester. Hasil analisis yang diperoleh sebesar $46 \%$ dari siswa yang tuntas dan untuk siswa yang tidak tuntas sebesar $54 \%$.

\section{c. Analisis Konsep}

Analisis konsep ini ditujukan untuk mata pelajaran memahami dasar-dasar elektronika, dengan kompetensi dasar memahami sifat-sifat komponen elektronika pasif. Indikatornya berupa menjelaskan karakteristik resistor, menjelaskan karakteristik kapasitor dan menjelaskan karakteristik induktor.

\section{Tahap Desain}

Tahap berikutnya yaitu tahap design (perancangan), pada tahap perancangan peneliti mulai merancang kompetensi dasar memahami sifat-sifat komponen elektronika pasif. Pada tahap perancangan mencakup beberapa aspek yaitu : 
a. Rancangan Slide Template Course Lab

Rancangan template Course Lab berguna untuk menarik perhatian siswa sehingga siswa tertarik untuk memperhatikan Course Lab sebelum melihat isinya.

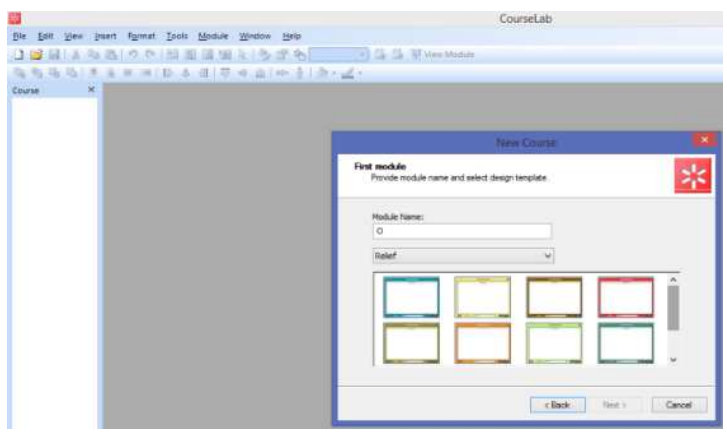

Gambar 2. Rancangan Slide Template Course Lab

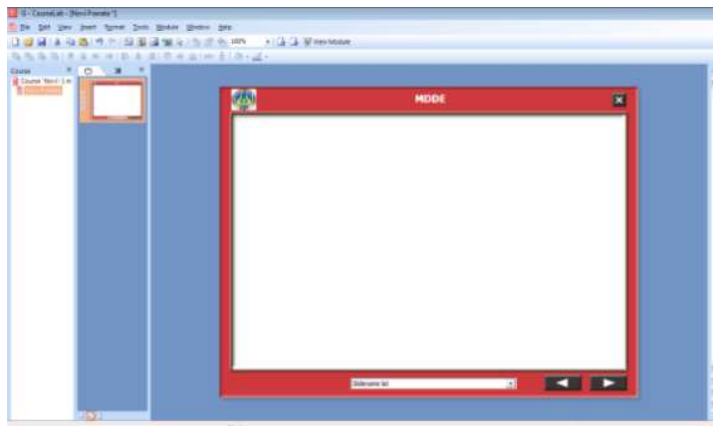

Gambar 3. Rancangan Slide Course Lab

b. Rancangan Isi

Pada tahap ini peneliti membuat rancangan isi Course Lab disesuaikan dengan struktur Course Lab. Dalam hal ini rancangan isi biasanya terbagi menjadi tiga yaitu :

1) Pembukaan

Di bagian ini harus mampu membuat siswa tertarik dan termotivasi untuk mendengarkan guru. Manfaatkan waktu sebaik-baiknya untuk merebut perhatian siswa. Karena ini akan menjadi momentum penting dari keseluruhan presentasi yang akan sampaikan.

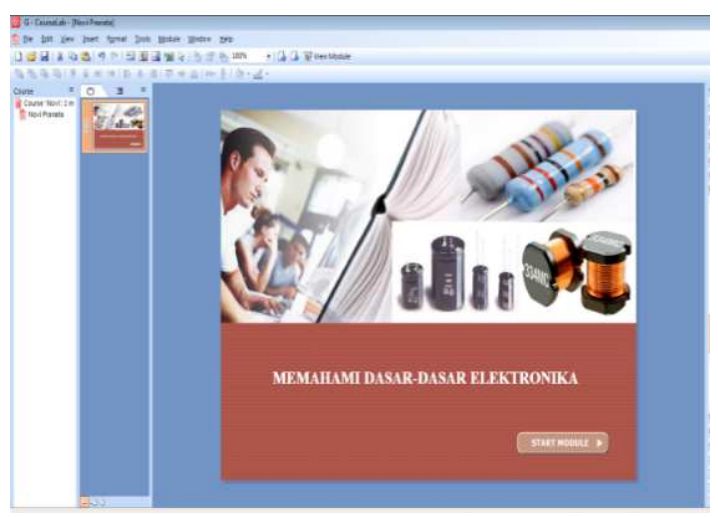

Gambar 4. Slide Pembukaan Pada Course Lab

2) Pembahasan

Pada tahap pembahasan peneliti menyajikan materi pembelajaran secara mendetail dan efisien. Artinya harus mampu memilih materi yang harus sampaikan dan mana yang tidak perlu disampaikan. Sehingga bisa dilihat dari kompetensi dan indikator yang ada.

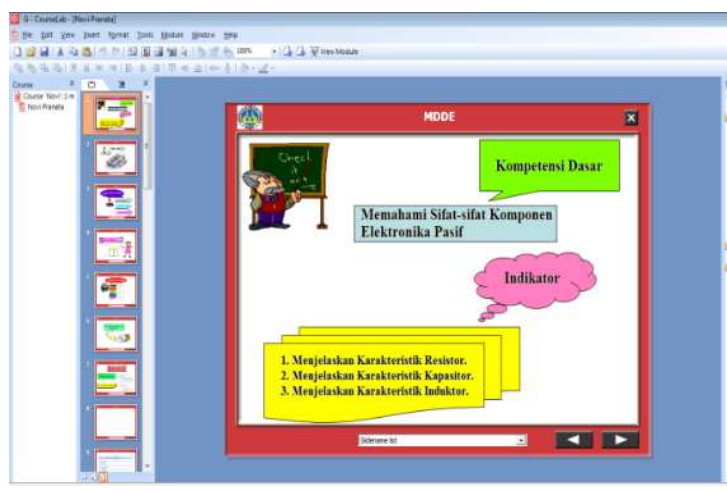

\section{Gambar 5. Slide Pembahasan Materi}

3) Penutup

Sama halnya dengan pembuka, bagian penutup juga memiliki peran yang sangat penting dalam presentasi. Penutup yang baik harus berkesan. Artinya harus meninggalkan sesuatu yang benarbenar melekat dalam pikiran siswa. 


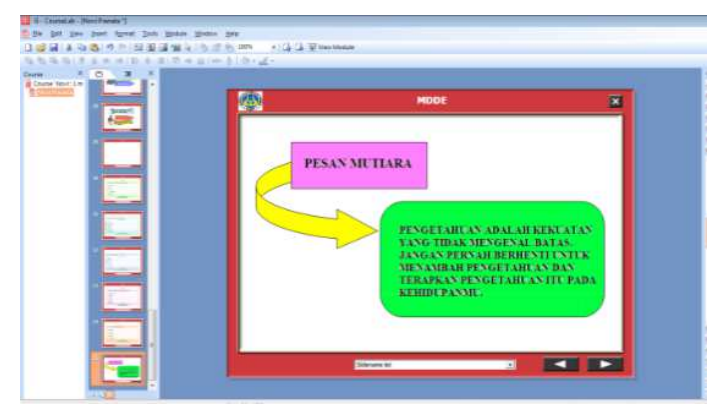

Gambar 6. Slide Penutup Pada Course Lab

c. Validasi oleh Tenaga Ahli

Pada penelitian ini Course Lab divalidasi oleh tenaga ahli pendidikan. Berdasarkan penilaian angket diperoleh jumlah skor penilaian oleh validator multimedia interaktif berbasis Course Lab adalah 110, 99 dan 113, maka diperoleh rata-rata skor penilaian oleh validator ini adalah 4,12 dari kategori interval 3,40 $\leq \mathrm{N} \leq 4,19$ maka hasil ratarata tersebut diperoleh dari hasil penilaian oleh validator terhadap Course Lab ini adalah "Valid" meskipun terdapat saran-saran yang diberikan oleh ketiga validator dan sudah diperbaiki sesuai saran tersebut.

\section{Tahap Development (Pengembangan)}

Dalam tahap design, telah di revisi dari masukan parah ahli, revisi produk tersebut direalisasikan menjadi produk yang siap diimplementasikan. Yang dilakukan pada tahap development yaitu sebagai berikut :

a. Pembuatan Produk

Pada tahap desain telah dirancang Course Lab yang akan di uji coba, kemudian pada tahap ini dimulailah pembuatan produk yang sesuai dengan struktur yang telah dirancang dan direvisi dari tenaga ahli.

b. Uji Coba Produk

Uji coba produk yang didesain menjadi produk yang siap diimplementasikan maka langkah selanjutnya penelitian dan pengembangan adalah uji coba. Pada tahap ini juga dilakukan evaluasi untuk mendapatkan informasi mengenai Course Lab yang dikembangkan.

Berdasarkan penilaian angket tersebut, diperoleh jumlah skor penilaian oleh guru mata pelajaran terhadap multimedia interaktif berbasis Course Lab adalah 50 dan diperoleh rata-rata skor penilaian oleh guru mata pelajaran terhadap Course Lab ini adalah 4,17 dari kategori interval 3,40 $\leq \mathrm{N} \leq 4,19$

maka hasil rata-rata tersebut diperoleh dari hasil penilaian guru mata pelajaran terhadap Course Lab ini adalah "Praktis". Namun ada sedikit komentar dan saran terhadap Course Lab yaitu media yang digunakan telah sesuai untuk mata pelajaran MDDE. Diharapkan dapat dipakai saat proses belajar mengajar.

Berdasarkan penilaian angket diperoleh jumlah skor angket mengenai tanggapan siswa terhadap multimedia interaktif berbasis Course Lab adalah 769. Dengan jumlah skor kriterium (N) terhadap respon siswa adalah 4,01 dari kategori interval 3,40 $\leq \mathrm{N} \leq 4,19$ maka dikategorikan "Praktis". Berdasarkan penilaian responden, dapat disimpulkan tanggapan siswa terhadap multimedia interaktif berbasis Course Lab memiliki respon yang positif.

\section{Tahap Implementation (Implementasi)}

Tahap implementasi meliputi penggunaan produk pengembangan untuk diaplikasikan dalam proses pembelajaran yang sudah didesain sedemikian rupa. Pada tahap ini Multimedia Interaktif Berbasis Course Lab divalidasi terlebih dahulu oleh tenaga ahli. Setelah dilakukan validasi dan dinyatakan layak sebagai Multimedia Interaktif maka uji coba akan dilakukan pada uji praktikalitas dan efektifitas. Pada uji praktikalitas dilakukan pada guru dan siswa menggunakan angket sebagai pengumpul data. Untuk uji efektifitas dilakukan pada siswa kelas XI TITL 1 Rombel B SMK Muhammadiyah 1 Padang. Dalam uji ini selain menggunakan angket sebagai pengumpul data, peneliti juga mengadakan proses pembelajaran dengan menggunakan Multimedia Interaktif yang sudah dikembangkan. 


\section{Tahap Evaluation (Evaluasi)}

Keefektifan dapat dilihat dari persentase ketuntasan belajar siswa kelas XI TITL 1 Rombel B melalui posttest terutama pada KD memahami sifat-sifat komponen elektronika pasif. Siswa yang telah mengikuti proses pembelajaran menggunakan multimedia interaktif berbasis Course Lab pada siswa kelas XI TITL 1 Rombel B SMK Muhammadiyah 1 Padang dengan hasil ketuntasan diperoleh yaitu sebesar 87,5\% dari 16 siswa terdapat 2 orang siswa yang tidak tuntas. Hal tersebut berarti ketuntasan klasikal melebihi $85 \%$ yang telah ditetapkan oleh Kurikulum Tingkat Satuan Pendidikan (KTSP).

Pada mata pelajaran Memahami DasarDasar Elektronika merupakan mata pelajaran produktif pada program keahlian Teknik Instalasi Tenaga Listrik. Mata pelajaran ini wajib diikuti oleh siswa kelas XI TITL. Namun siswa masih banyak yang belum memahaminya. Dengan adanya pengembangan multimedia interaktif berbasis Course Lab ini siswa terbantu dalam memahami mata pelajaran karena dapat menggabungkan lebih dari satu media didalam satu Software sehingga memberikan gambaran jelas tentang memahami dasar-dasar elektronika. Multimedia interaktif ini sudah dikembangkan menggunakan Software Course Lab.

Penelitian dan pengembangan multimedia interaktif ini menggunakan model pengembangan ADDIE yaitu: Analysis, Design, Development, Implementation, Evaluation. Dengan tujuan utama dari penelitian pengembangan multimedia interaktif ini adalah untuk menghasilkan multimedia yang valid, praktis dan efektif. Analysis atau analisis ialah tahap masalah dasar yang dibutuhkan dalam pengembangan multimedia berbasis Course Lab. Pada tahap analisis memiliki tiga bagian analisis yaitu analisis kebutuhan, analisis siswa dan analisis konsep. Design atau perancangan ialah tahap rancangan awal pembuatan multimedia interaktif mulai dari pembuatan slide, pengumpulan materi pembelajaran dan desain multimedia. Pada tahap ini dilakukan uji validitas terhadap tenaga ahli. Development atau pengembangan ialah tahap uji coba terhadap guru mata pelajaran dan siswa. Implementation atau implementasi ialah tahap dimana multimedia interaktif telah siap digunakan dalam proses pembelajaran yang sesungguhnya karena telah dilakukan uji validitas dan praktikalitas. Evaluation atau evaluasi ialah tahap yang dilakukan untuk mengetahui efektivitas multimedia interaktif berbasis Course Lab.

Validitas multimedia interaktif diperoleh dari lembar validasi yang dilakukan oleh tim validator. Diperoleh hasil validasi sebesar 4,12 dengan kategori "Valid". Dengan demikian multimedia interaktif yang telah dikembangkan menunjukkan bahwa multimedia interaktif telah memenuhi uji kelayakan.

Praktikalitas multimedia interaktif dengan memberikan angket praktikalitas kepada responden yaitu guru mata pelajaran MDDE dan kepada siswa kelas XI TITL 1 Rombel B sebanyak 16 siswa. Hasil praktikalitas yang diperoleh dari guru mata pelajaran dengan nilai 4,17 dalam kategori "Praktis". Hasil praktikalitas yang diperoleh dari siswa dengan nilai rata-rata 4,01 dikategorikan "Praktis". Hasil ini berarti bahwa multimedia interaktif telah memenuhi 5 pertimbangan kepraktisan yang dikemukakan oleh Sukardi yaitu, kemudahan penggunaan, efektifitas waktu pembelajaran, manfaat, daya tarik produk dan ekivalensi [5].

Efektivitas dilakukan dengan cara melihat ketuntasan hasil belajar siswa setelah menggunakan multimedia interaktif berbasis Course Lab. Untuk melihat hasil belajar siswa yang telah menggunakan multimedia interaktif berbasis Course Lab dalam proses pembelajaran dilakukan melalui Posttest. Hasil Posttest menunjukkan ketuntasan belajar siswa sebesar 87,5\% dari 16 siswa dengan kategori efektif. Hasil tersebut menunjukkan bahwa ketuntasan belajar siswa yang diperoleh sudah memenuhi standar ketuntasan klasikal yang telah ditetapkan KTSP yaitu $85 \%$. Dengan demikian dapat disimpulkan bahwa multimedia interaktif yang dikembangkan dinyatakan efektif.

Multimedia interaktif berbasis Course Lab yang dikembangkan dan dinyatakan valid, praktis, dan efektif. Jadi dapat disimpulkan bahwa multimedia interaktif berbasis Course Lab dapat dipergunakan dengan baik dalam proses pembelajaran pada mata pelajaran Memahami Dasar-Dasar Elektronika.

Pengembangan multimedia interaktif ini tidak terbatas pada mata pelajaran Memahami Dasar-Dasar Elektronika saja, hal ini dapat dibuktikan dengan adanya hasil penelitian yang relevan pengembangan multimedia interaktif 
yang dilakukan pada mata pelajaran berbeda dan sekolah yang berbeda.

Pada penelitian pengembangan multimedia interaktif berbasis Course Lab ini memiliki hambatan-hambatan diantaranya kurangnya komputer di jurusan TITL membuat proses penelitian sedikit terhambat. Namun hambatan tersebut dapat diatasi dengan cara meminjam notebook/ laptop lain agar, tidak menganggu proses pembelajaran. Dengan demikian proses penelitian berjalan dengan lancar dan menghasilkan multimedia interaktif berbasis Course Lab yang valid, praktis dan efektif.

\section{KESIMPULAN}

Berdasarkan penelitian yang telah dilakukan dengan hasil yang telah diuraikan pada BAB IV, maka dapat disimpulkan penelitian pengembangan menghasilkan sebuah produk multimedia interaktif berbasis Course Lab untuk mata pelajaran Memahami Dasar-Dasar Elektronika (MDDE) yang Valid, Praktis dan Efektif. Dengan rincian hasil pengembangan multimedia interaktif menggunakan Course Lab sebagai berikut.

1. Hasil validasi multimedia interaktif berbasis Course Lab sebesar 4,12 dengan kategori interval 3,40 $\leq \mathrm{N} \leq 4,19$. Dengan demikian bahwa multimedia interaktif yang dikembangkan dinyatakan valid.

2. Hasil uji praktikalitas kepada guru mata pelajaran dan siswa mengenai multimedia interaktif menggunakan Course Lab diperoleh dengan tingkat kepraktisan dari guru mata pelajaran sebesar 4,17 pada kategori interval $3,40 \leq \mathrm{N} \leq 4,19$ dan tanggapan siswa mengenai multimedia interaktif diperoleh sebesar 4,01 pada kategori interval 3,40 $\leq \mathrm{N}$ $\leq 4,19$. Dengan demikian dapat disimpulkan bahwa multimedia interaktif berbasis Course Lab yang telah dikembangkan dinyatakan praktis.

3. Efektivitas penggunaan multimedia interaktif berbasis Course Lab diperoleh dari tingkat ketuntasan klasikal siswa yaitu $87,5 \%$ dari Kriteria Ketuntasan Minimum (KKM) sebesar 80 sehingga multimedia interaktif berbasis Course Lab yang dikembangkan sudah efektif untuk digunakan dalam proses pembelajaran.

\section{DAFTAR PUSTAKA}

[1] F. Eliza, R. Fadli, A.Mardani, “ Pembelajaran Berbasis Trainer Elektro Magnetik Untuk Meningkatkan Hasil Belajar Siswa", Jurnal Edukasi Elektro, Vol. 2, No. 1, Mei 2018.

[2] Azhar Arsyad. Media Pembelajaran. Jakarta: PT. Raja Grafindo Persada. 2004.

[3] Abdul Munif. Pembuatan Bahan Ajar Multimedia Interaktif Menggunakan Course Lab. 2013. Website: http://www.vedcmalang.com diakses 15 April 2017.

[4] Sugiyono. Metode Penelitian Pendidikan Kualitatif, Kuantitatif, dan $R \& D$. Bandung: Alfabeta. 2010.

[5] Sukardi. Evaluasi Pendidikan. Jakarta: Bumi Aksara. 2011. 